\title{
Multi-Programmatic and Institutional Computing Capacity Resource Attachment 3 Proposal Evaluation and Proposal Preparation Instructions
}

\author{
M. Seager
}

U.S. Department of Energy

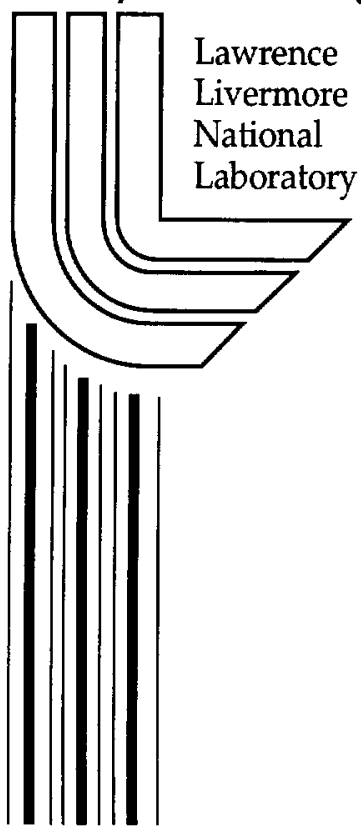

April 15, 2002

Livermore

National

Laboratory 



\section{DISCLAIMER}

This document was prepared as an account of work sponsored by an agency of the United States Government. Neither the United States Government nor the University of California nor any of their employees, makes any warranty, express or implied, or assumes any legal liability or responsibility for the accuracy, completeness, or usefulness of any information, apparatus, product, or process disclosed, or represents that its use would not infringe privately owned rights. Reference herein to any specific commercial product, process, or service by trade name, trademark, manufacturer, or otherwise, does not necessarily constitute or imply its endorsement, recommendation, or favoring by the United States Government or the University of California. The views and opinions of authors expressed herein do not necessarily state or reflect those of the United States Government or the University of California, and shall not be used for advertising or product endorsement purposes.

This work was performed under the auspices of the U.S. Department of Energy by the University of California, Lawrence Livermore National Laboratory under Contract No. W-7405-Eng-48.

This report has been reproduced directly from the best available copy.

Available electronically at http://www.doe.gov/bridge

Available for a processing fee to U.S. Department of Energy

and its contractors in paper from

U.S. Department of Energy

Office of Scientific and Technical Information

P.O. Box 62

Oak Ridge, TN 37831-0062

Telephone: (865) 576-8401

Facsimile: (865) 576-5728

E-mail: reports@adonis.osti.gov

Available for the sale to the public from

U.S. Department of Commerce

National Technical Information Service

5285 Port Royal Road

Springfield, VA 22161

Telephone: (800) 553-6847

Facsimile: (703) 605-6900

E-mail: orders@ntis.fedworld.gov

Online ordering: http://www.ntis.gov/ordering.htm

OR

Lawrence Livermore National Laboratory

Technical Information Department's Digital Library

http://www.llnl.gov/tid/Library.html 



\title{
University of California Lawrence Livermore National Laboratory
}

\section{Multi-Programmatic and Institutional Computing Capacity Resource}

\author{
Attachment 3 \\ Proposal Evaluation \\ and \\ Proposal Preparation Instructions
}

B525176

Version 1

April 15, 2002

Science in the National Interest

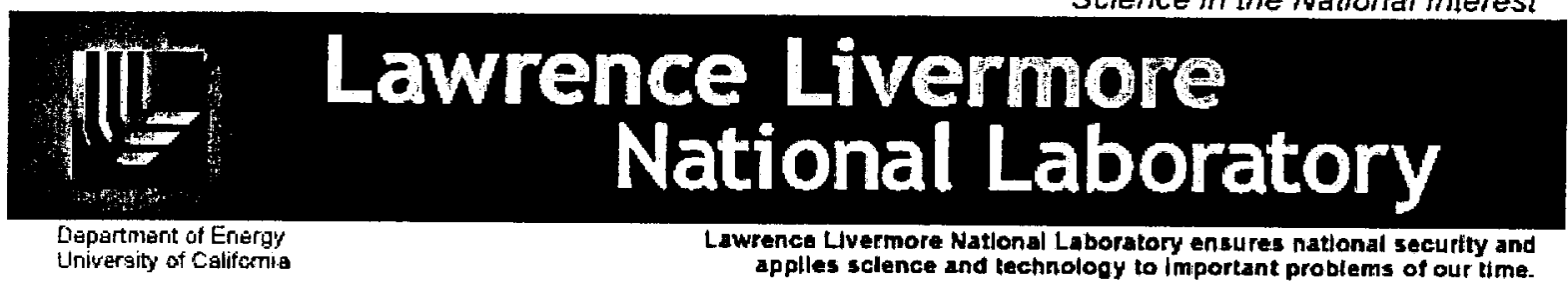




\section{TABLE OF CONTENTS}

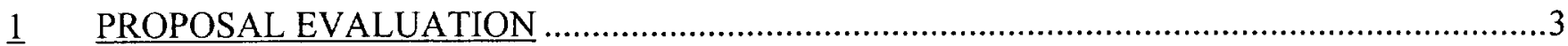

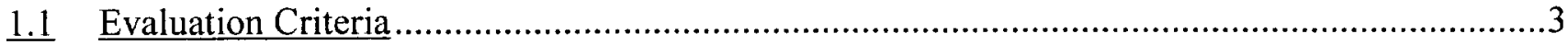

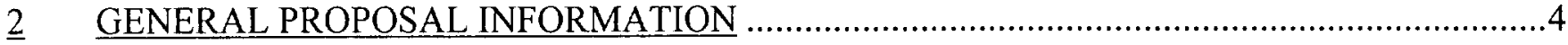

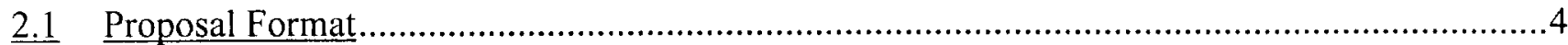

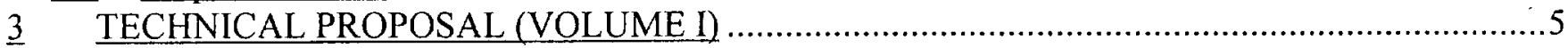

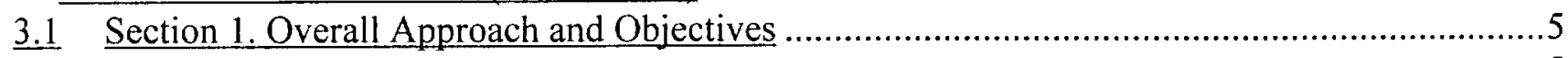

$\underline{3.2}$ Section 2. System Architecture and Overview .............................................................5

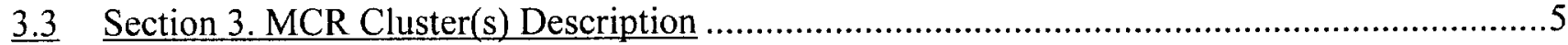

$\underline{3.4}$ Section 4. Reliability, Availability, Serviceability and Maintenance.......................................6

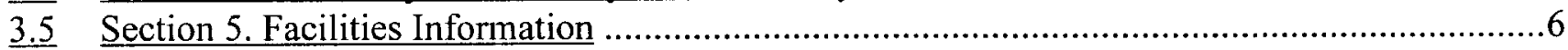

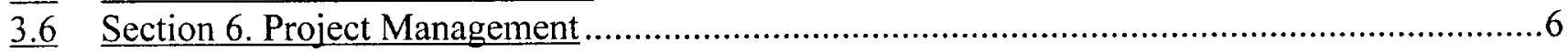

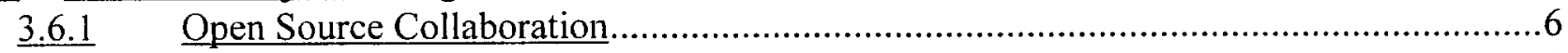

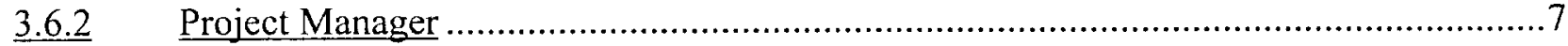

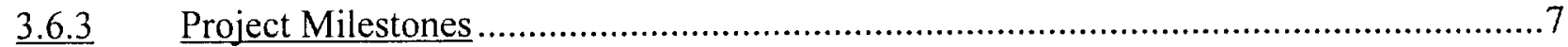

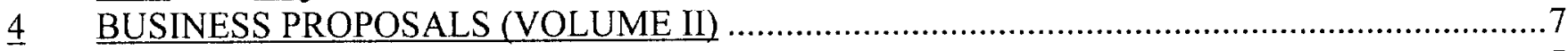

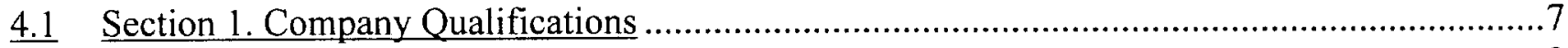

$\underline{4.2}$ Section 2. Linux Product Roadmap .......................................................................

4.3 Section 3. Proposed Open Source Development Partnership ..............................................8

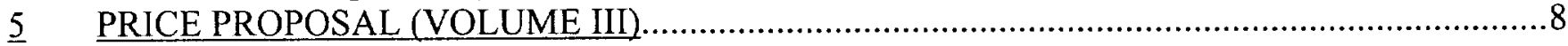

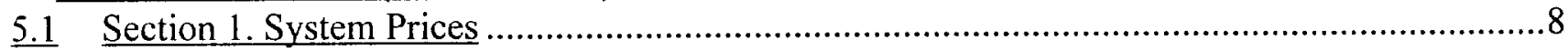

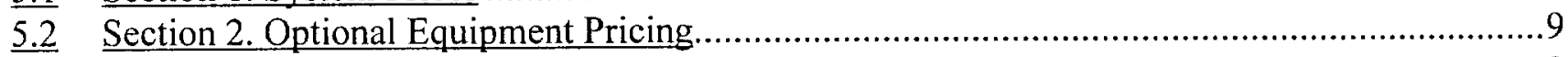

5.3 Section 3. Lower-Tier Subcontractor Price Information ..............................................9

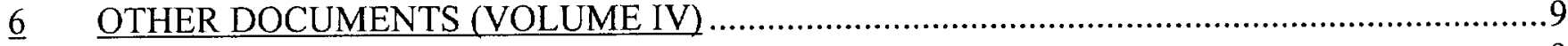

$\underline{6.1}$ Section 1. Software Branding and Licensing .............................................................

$\underline{6.2}$ Section 2. System Warranty Information ................................................................. 


\section{PROPOSAL EVALUATION}

\subsection{Evaluation Criteria}

The Offeror's proposal must demonstrate compliance with the mandatory requirements. The University's assessment of each proposal will form the basis for selection using the following criteria.

\section{PERFORMANCE FEATURES}

\section{Technical Proposal}

How well Offeror's technical proposal addresses the statement of work requirements.

- How well the technical proposal meets or exceeds the desirable technical requirements.

- How well the proposed solution meets the overall programmatic objectives expressed in the RFP.

- The proposed hardware and software support model and how will this model provide at least three years of practical system maintenance. (I.e., will the maintenance model work in practice?)

\section{Feasibility \& Schedule Credibility}

The likelihood of the Offeror's system will work and the proposed delivery will happen.

The realism of the proposed timeline given the Offeror's manufacturing and testing facilities and the quality of the project plan and management.

How well the proposed technical approach aligns with the Offeror's corporate product roadmap.

The realism and completeness of the project Gantt chart?

The level of corporate commitment to this effort.

The University's assessment of the risks associated with the proposed solution to both the Offeror and the University.

\section{SUPPLIER ATTRIBUTES}

\section{Capability}

The Offeror's experience and past performance in providing high-end computing systems and its demonstrated commitment to high-end computing customers.

- The quality and scope of the Offeror's performance record.

- The Offeror's demonstrated ability to meet schedule and delivery promises.

- The Offeror's ability to comply with the required or proposed delivery and performance schedules.

The contribution of the management plan and key personnel contribute to successful and timely completion of the work.

The Offeror's financial condition.

- The existence of adequate financial resources to perform the subcontract.

The Offeror's experience and past performance in providing solutions based on Open Source.

- The credibility of the Offeror's Linux cluster strategy.

- The alignment of this proposal with the Offeror's Linux strategy.

The credibility of the Offeror's proposal based on Open Source development and support. 
- The Open Source technology offered as part of the partnership.

- The development and support resources available to the partnership.

\section{AFFORDABILITY}

- Reasonableness of the total proposed price and the prices of proposed components and options in a competitive environment.

- The proposed price compared to the perceived value.

- The life cycle costs compared to those of the competition.

- The price trade offs and options embodied in the Offeror's proposal.

\section{GENERAL PROPOSAL INFORMATION}

Each Offeror must submit two originals and one electronic copy of their proposal including other written information.

\subsection{Proposal Format}

Please submit TWO (2) paper copies and ONE (1) electronic copy of your proposal as indicated. All proposal copies should be presented using $81 / 2$ by 11 -inch paper in loose-leaf binders. The page limit for the Technical Proposal (Volume I) is 50 pages and for the Business Proposal (Volume II) is 20 pages, and is defined as consecutively numbered pages. There is no page limit for the Price Proposal (Volume III) and Other Documents (Volume IV) portions of the proposals. At least 12-point font should be used and the paper copies must be printed on one side only. Offerors must also submit ONE (1) copy of their entire proposal electronically in Microsoft Office 2000 (Word, Excel, PowerPoint, Project), PDF format, or Rich Text Format. Submission of your proposal by electronic media (e-mail or FAT formatted 100MB ZIP disks or ISO standard CD-ROM) shall be considered by the University to be Certification that the media is virus free. Should any inconsistencies exist between the Offeror's paper copy proposal and the documents submitted on electronic media, the paper copy form of the Offeror's proposal shall take precedence.

Table 1

\section{Proposal Format}

\begin{tabular}{|l|}
\hline \multicolumn{1}{|c|}{ VOLUME-SECTION NUMBER } \\
\hline Volume I Technical Proposal (50 page limit total) \\
Section 1. Overall Approach and Objectives \\
Section 2. System Architecture and Overview \\
Section 3. MCR Cluster Description \\
Section 4. Reliability, Availability, Serviceability and Maintenance \\
Section 5. Facilities Information \\
Section 6. Project Management \\
\hline Volume II Business Proposal (20 page limit total) \\
Section 1. Company Qualifications \\
Section 2. Linux Product Roadmap \\
Section 3. Proposed Open Source Development Partnership \\
\hline Volume III Price Proposal (no page limit) \\
\hline
\end{tabular}




\begin{tabular}{|l|}
\hline \multicolumn{1}{|c|}{ VOLUME-SECTION NUMBER } \\
\hline Section 1. System Prices \\
Section 2. Options Prices \\
Section 3. Lower-Tier Subcontractor Price Information \\
\hline Volume IV Other Documents (no page limit) \\
Section 1. Software Branding and Licenses, if applicable \\
Section 2. System Warranty Information \\
Section 3. Representations and Certifications Form \\
\hline
\end{tabular}

\section{TECHNICAL PROPOSAL (VOLUME I)}

In the Technical Proposal, the Offeror shall describe the systems proposed. This shall be written in the form of an integrated narrative and shall include a point-by-point response to the technical requirements contained in the Statement of Work. This narrative shall include a description of each of the proposed MCR systems. The Technical Proposal shall be divided into the following tabbed sections:

\subsection{Section 1. Overall Approach and Objectives}

Discuss the Offeror's approach to responding to this RFP and meeting the M\&IC programmatic objectives. Discuss the overall software and hardware build strategy for the 960 node MCR cluster. Give a summary of what will be delivered when.

\subsection{Section 2. System Architecture and Overview}

The system architecture and overview section of the technical proposal shall contain the following information:

- Architecture - An executive summary that provides an architecture of the proposed MCR solution. The architecture should cover three areas: 1) overall system architecture; 2) architecture of each scalable unit; 3) Architectural description of each node type proposed. Each architectural description will delineate major functional and performance capabilities.

- Deliverables - A list of hardware and software items to be delivered and the delivery dates, and quantities. This information shall be provided for items one level below the subsystem level.

- Definitions and Acronyms - A definition of terms, acronyms, and abbreviations used in the document.

\subsection{Section 3. MCR Cluster(s) Description}

This section shall contain a detailed description of the proposed MCR cluster. This includes the a detailed response to each requirement in section 3 of the RFP. The response shall include the requirement number and text with Offeror's response below. If alternative approaches are chosen rather than those given as examples, then the alternative approach should be outlined in the same fashion as the example RFP requirements. For instance, if $1 U$ Dual Pentium 4/Xeon nodes are offered rather than the example requirements specifying $2 \mathrm{U}$ nodes, then the racking and scalable unit requirements would be different (e.g., fewer racks would be required), but follow the same general outline. 


\subsection{Section 4. Reliability, Availability, Serviceability and Maintenance}

This section shall contain a detailed description all facts relating to the reliability, availability and serviceability of the bid MCR cluster(s). In particular, provide the Mean Time Between Failures (MTBF) calculation for each MCR cluster bid. This calculation shall be performed using a recognized standard. Examples of such standards are Military Standard (Mil Std) 756, Reliability Modeling and Prediction, which can be found in Military Handbook 217F, and the Sum of Parts Method outlined in Bellcore Technical Reference Manual 332. In the absence of relevant technical information in the proposal, the University is forced to make pessimistic reliability, availability and serviceability assumptions in evaluating the proposal. This section shall describe in detail the proposed hardware and software maintenance strategy throughout the life of the subcontract. Include the level of service you intend to provide at various points during the subcontract period (i.e. system build, system installation, acceptance testing, post acceptance, etc.). For hardware maintenance, specify the length of time (from initial purchase of parts for MCR build) that replacement parts will be IDENTICAL (e.g., same speed, same motherboards, etc.). In addition, delineate replacement parts policy once bid commodity components reach end of life until the end of the required three years of hardware maintenance.

Specific hardware maintenance roles and responsibilities for LLNL, Offeror, BlueArc and Quadrics should be delineated. Specific elements of the spare parts cache and on-site hot spares shall be itemized. Failed hardware return mechanism and parts cache refresh policy shall be discussed. Software maintenance procedures shall be delineated for provided software components. For instance, describe how are software patches provided to LLNL and how are they will be tested.

\subsection{Section 5. Facilities Information}

Floor Plans. Provide a separate floor plan for each of the MCR clusters proposed, including any subsystems (e.g., I/O cabinets, disks, cabling, external networking, etc.). The floor plan will include a diagram of asset placement, as well as floor-loading information, and underfloor clearance requirements and placement and type of required electrical outlets.

Provide the estimated total amount of power in $\mathrm{kW}$ (kilowatts) required for each of the MCR clusters proposed, including any subsystems (e.g., I/O cabinets, disks, cabling, external networking, etc.). The plan will also include the estimated total amount of cooling in BTU (British Thermal Units) or Tons AC required for each of the MCR clusters proposed. List any other facilities requirements.

\subsection{Section 6. Project Management}

The following Project Management information shall be provided as part of the Offeror's proposal:

\subsubsection{Open Source Collaboration}

This section may discuss how the partnership will collaborate, over the term of this contract and beyond, on open source development. Of particular interest is how the open source development efforts feed into the delivery of MCR cluster and their support and enhancement over the life of the contract. Include a model of how you think the LC Dev 
cluster should be used to support development and software service activities (e.g., bug fix testing, etc).

\subsubsection{Project Manager}

Name a project manager that will provide supervision within the corporation for the building, testing, delivery and acceptance of the proposed MCR clusters. Provide the resume of this individual and a description of the roles and responsibilities in the format shown in Appendix B. Also indicate the level of authority this individual will carry within the corporation for the management of this activity.

\subsubsection{Project Milestones}

Provide a draft Gantt chart and work-breakdown structure (WBS), including milestones, for the project in the form of a Microsoft Project 2000 data file with the proposal submission. Indicate which items are being subcontracted to third parties and which items are on the critical path. Also, include a draft pre-ship test plan and a draft acceptance test plan in Microsoft Word 2000 format.

\section{BUSINESS PROPOSALS (VOLUME II)}

\subsection{Section 1. Company Qualifications}

Provide the following background information on those contracts during the past two years that the offeror considers the most comparable to the requirements of this RFP in terms of providing high-end computing systems and working with high-end customers and partners to advance the high-end computing state-of-the-art: contract number; contract type; contract value; contract effective date and term; place of performance; client contacts (include the name and phone number of contractual contact and the name and phone number of technical contact); similarities to University requirements. Offerors are encouraged to include a selfassessment of their performance on these projects including what went well and what did not. Offerors may discuss the latter in the context of a lessons learned scenario.

To assist the University in assessing the financial capability of the Offeror, provide any or all of the following:

a. Audited balance sheets and profit and loss statements for the Offeror's company for the last six (6) completed financial quarters, including interim statements for the current quarter. Also provide copies of your Form 10-K filed with the Securities and Exchange Commission for the past two (2) fiscal years, plus any 10-Q Forms filed since the last Form 10-K.

b. Furnish affirmative assurance, such as endorsements from financial institutions, that your company has sufficient funds necessary to perform the work.

c. State what percentage of your performing organization's estimated total business during the period of performance this proposed subcontract will represent.

d. State the distribution of your last complete fiscal year's sales volume among commercial business, Government prime contracts, and subcontracts under Government prime contracts.

e. Provide a current Dun and Bradstreet Payment Analysis Report (PAR). 
Please provide any other relevant and useful information about the financial health of the corporation that will assist the University in assessing the financial capability of the Offeror.

\subsection{Section 2. Linux Product Roadmap}

Describe the corporation's Linux product roadmap for the next two years. Include hardware and software offerings. Provide information that will give an indication of the depth and scope of the product roadmap as well as the products targeted specifically at highperformance Linux clustering. Indicate the open source partnerships the corporation is involved in and how the results of these effort factor into future products.

\subsection{Section 3. Proposed Open Source Development Partnership}

The Offeror may provide information on the capabilities of the corporation to engage in an open source development partnership and meet the goals set out in Statement of Work section 1.7. This information should include corporation's qualifications as a cluster provider; corporation's qualifications as an open source development organization; cluster product roadmap and comparison to the overall MCR strategy; the willingness of the corporation to participate in the open source development, with other partners, of key missing HPTC cluster technology components such as scalable parallel file systems and cluster resource scheduling. If the Offeror has technology, such as a scalable parallel file system or cluster management tools or cluster resource scheduling that could be contributed to the overall MCR software effort please indicate that as well.

\section{PRICE PROPOSAL (VOLUME III)}

\subsection{Section 1. System Prices}

Offerors shall fully complete the price schedules contained in Appendix A of this Attachment, in accordance with the instructions contained herein. Modifications to the spreadsheets may be made as necessary.

Offerors shall provide a firm fixed price for each system offered. A separate firm fixed-price shall also be provided for each alternate proposal submitted. The total price proposed for each system shall include all software and software license costs, unless explicitly noted. The firm fixed-price shall also include all delivery and installation costs. Maintenance prices shall be based on next business day 8:00AM-5:00PM, Pacific Time Zone, service for all systems proposed for the duration of the contract.

An entry must be made for each line item. If the price of a line item is being offered at "No Charge" to the University insert "NC" for that entry. If a line item cannot be separately priced, insert "NSP" for that entry. In the description column, the Offeror must also insert the entry "Note _." directing the University to the "Note" that provides a narrative explanation for all "NSP" entries, identifying which line item includes that price. All accompanying notes shall be included at the end of the price schedule. 


\subsection{Section 2. Optional Equipment Pricing}

Offerors shall fully complete the Optional Equipment Pricing table contained in Appendix A. Pricing should be for a single additional node rack. An entry must be made for each line item. Offerors may include additional options that they think would be of interest to the University. Offeror-defined options must include relevant technical, business, and price information in the appropriate proposal volume.

\subsection{Section 3. Lower-Tier Subcontractor Price Information}

If the Offeror is proposing to use lower-tier subcontractors, price information for each

Subcontractor shall be furnished in the same format and level of detail as prescribed for the Offeror.

\section{OTHER DOCUMENTS (VOLUME IV)}

\subsection{Section 1. Software Branding and Licensing}

Submit all branding or certification of software standards adherence required in section 2 .

Submit licensing policies for all categories of software (compilers, libraries, application development tools, etc.) being provided under this Subcontract. Identify all third-party software. Include policies for cluster-wide right-to-use licenses for an unlimited number of users for all software delivered under this Subcontract. Include any required Software License or Maintenance Agreement as well as any licensing requirements for source code. The following conditions must be incorporated in any resulting license agreement or maintenance agreement:

a. The governing laws of the state of California;

b. The right of assignment of any agreement to the Department of Energy (DOE) for assignment to any succeeding prime contractor to the University. An Offeror's proposal may be considered non-compliant in the event the Offeror and the University cannot mutually agree to terms and conditions contained in any Software License or Maintenance Agreement.

\subsection{Section 2. System Warranty Information}

Provide warranty information for all Offeror-provided items as well as any third-party subcontracted items. 


\section{Appendix A \\ Price Schedules}

The following Price Schedule 1 shall be completed for any of the MCR cluster proposed. If the Offeror is not proposing one or more of the cluster components, then that section should be labeled with "NOT BID".

\begin{tabular}{|c|c|c|c|}
\hline \multicolumn{4}{|c|}{$\begin{array}{l}\text { Price Schedule } 1 \\
\text { MCR Cluster }\end{array}$} \\
\hline & Item Price & Quantity & Ext Total \\
\hline \multicolumn{4}{|l|}{ MCR Cluster: } \\
\hline \multicolumn{4}{|l|}{ Compute Nodes } \\
\hline \multicolumn{4}{|l|}{ 2.0 GiB Compute Node Memory Kit } \\
\hline \multicolumn{4}{|l|}{ Compute Node Local Disk } \\
\hline \multicolumn{4}{|l|}{ Login Nodes } \\
\hline \multicolumn{4}{|l|}{ 4.0 GiB Login Node Memory Kit } \\
\hline \multicolumn{4}{|l|}{ Login Node Local Disk } \\
\hline \multicolumn{4}{|l|}{ MDS Nodes } \\
\hline \multicolumn{4}{|l|}{ MDS Memory } \\
\hline \multicolumn{4}{|l|}{ MDS Local Disk } \\
\hline \multicolumn{4}{|l|}{ MDS Shared Meta Data Disk } \\
\hline \multicolumn{4}{|l|}{ Rack 42U } \\
\hline \multicolumn{4}{|l|}{ Rack 47U } \\
\hline \multicolumn{4}{|l|}{ SPC \& RPC (IceBox or Equivalent) } \\
\hline \multicolumn{4}{|l|}{ Cisco 3548-XL-EN } \\
\hline \multicolumn{4}{|l|}{ Management Ethernet Cables } \\
\hline \multicolumn{4}{|l|}{ Integration and testing } \\
\hline \multicolumn{4}{|l|}{ Quadrics QsNet Elan3 Installation } \\
\hline \multicolumn{4}{|l|}{ GA621 1000Base-SW Installation } \\
\hline \multicolumn{4}{|l|}{ Linux boot image installation } \\
\hline \multicolumn{4}{|l|}{ Shipping } \\
\hline \multicolumn{4}{|l|}{ Installation at LLNL } \\
\hline \multicolumn{4}{|l|}{ 3yrs Hardware Maintenance } \\
\hline \multicolumn{4}{|l|}{ 3yrs Software Maintenance } \\
\hline \multicolumn{4}{|l|}{ Other (List Each Item) } \\
\hline \multicolumn{4}{|l|}{ MCR Cluster Subtotal: } \\
\hline \multicolumn{4}{|l|}{$\begin{array}{l}\text { Hot Spare Cluster and On-Site } \\
\text { Spares }\end{array}$} \\
\hline \multicolumn{4}{|l|}{ Compute Nodes } \\
\hline 2.0 GiB Compute Node Memory Kit & & & \\
\hline Compute Node Local Disk & & & \\
\hline Login Node & & & \\
\hline 4.0 GiB Login Node Memory Kit & & & \\
\hline Rack 42U & & & \\
\hline SPC \& RPC (IceBox or Equivalent) & & & \\
\hline
\end{tabular}




\begin{tabular}{|l|l|l|l|}
\hline \multicolumn{5}{|c|}{$\begin{array}{l}\text { Price Schedule 1 } \\
\text { MCR Cluster }\end{array}$} \\
\hline & Item Price & Quantity & Ext Total \\
\hline Cisco 3548-XL-EN & & & \\
\hline Management Ethernet Cables & & & \\
\hline Integration and testing & & & \\
\hline Linux boot image installation & & & \\
\hline Shipping & & & \\
\hline Installation at LLNL & & & \\
\hline Other on-site FRUs (List Each Item) & & & \\
\hline Other (List Each Item) & & & \\
\hline MCR HSC and On-Site Spares \\
Subtotal:
\end{tabular}

The following Price Schedule 2 shall be completed for any of the MCR clusters proposed. If the Offeror is not proposing one or more of the cluster components, then that section should be labeled with "NOT BID".

\begin{tabular}{|l|l|l|l|}
\hline \multicolumn{3}{|c|}{ Price Schedule 2 } \\
Optional Equipment \\
\hline Options: & Item Price & Quantity & Ext Price \\
\hline $\begin{array}{l}\text { Additional Compute Node Scalable } \\
\text { Unit: }\end{array}$ & & & \\
\hline Compute Nodes & & & \\
\hline 2.0 GiB Compute Node Memory Kit & & & \\
\hline Compute Node Local Disk & & & \\
\hline 47U Rack & & & \\
\hline 42U Rack & & & \\
\hline SPC \& RPC (IceBox or Equivalent) & & & \\
\hline Cisco 3548-XL-EN & & & \\
\hline Management Ethernet Cables & & & \\
\hline Integration and testing & & & \\
\hline Quadrics QsNet Elan3 Installation & & & \\
\hline Linux boot image installation & & & \\
\hline Shipping & & & \\
\hline Installation at LLNL & & & \\
\hline 3yrs Hardware Maintenance & & & \\
\hline 3yrs Software Maintenance & & & \\
\hline Other (List Each Item) & & & \\
\hline \multicolumn{1}{|c|}{ Compute Node Rack Subtotal: } & & & \\
\hline
\end{tabular}




\begin{tabular}{|l|l|l|l|}
\hline \multicolumn{1}{|c|}{ Optional Equipment } \\
\hline Additional Compute Node Rack: & & & \\
\hline Compute Nodes & & & \\
\hline 2.0 GiB Compute Node Memory Kit & & & \\
\hline Compute Node Local Disk & & & \\
\hline 42U Rack & & & \\
\hline SPC \& RPC (IceBox or Equivalent) & & & \\
\hline Cisco 3548-XL-EN & & & \\
\hline Management Ethernet Cables & & & \\
\hline Integration and testing & & & \\
\hline Quadrics QsNet Elan3 Installation & & & \\
\hline Linux boot image installation & & & \\
\hline Shipping & & & \\
\hline Installation at LLNL & & & \\
\hline 3yrs Hardware Maintenance & & & \\
\hline 3yrs Software Maintenance & & & \\
\hline Other (List Each Item) & & & \\
\hline Compute Node Rack Subtotal: & & & \\
\hline & & & \\
\hline Additional Options: & & & \\
\hline $\begin{array}{l}\text { 4.0 GiB Memory Kit for Compute } \\
\text { Node }\end{array}$ & & & \\
\hline 3yrs Maintenance for 4.0 GiB \\
Memory Kit & & & \\
\hline & & & \\
\hline & & & \\
\hline & & & \\
\hline
\end{tabular}




\section{Appendix B}

\section{Resume Format}

Name:

Proposed Title/Assignment on Contract:

Experience Summary: (A succinct summary of overall experience and capabilities including the name and phone number of the client that may be used for reference checking):

Current Assignment (Include description and from/to dates):

Current Client/Customer (Include current address and telephone number):

\section{Education:}

\section{Technical Qualifications:}

\section{Description(s) of Experience relevant to Proposed Contract Assignment:}

\section{Provide Three Business Related References:}

\section{List Awards/Honors/Publications:} evaluation process. 
